\title{
GMR
}

\section{Biometry and diversity of Arabica coffee genotypes cultivated in a high density plant system}

\author{
W.N. Rodrigues', M.A. Tomaz ${ }^{2}$, M.A.G. Ferrão ${ }^{3}$, L.D. Martins' ${ }^{1}$, T.V. Colodetti', \\ S.V.B. Brinate ${ }^{1}$, J.F.T. Amaral ${ }^{4}$, F.M. Sobreira ${ }^{5}$ and M.A. Apostólico ${ }^{6}$ \\ 1Programa de Pós-Graduação em Produção Vegetal, Centro de Ciências Agrárias, \\ Universidade Federal do Espírito Santo, Alegre, ES, Brasil \\ ${ }^{2}$ Departamento de Agronomia, Centro de Ciências Agrárias, \\ Universidade Federal do Espírito Santo, Alegre, ES, Brasil \\ ${ }^{3}$ Empresa Brasileira de Pesquisa Agropecuária (Embrapa Café), Vitória, ES, Brasil \\ ${ }^{4}$ Departamento de Engenharia Rural, Centro de Ciências Agrárias, \\ Universidade Federal do Espírito Santo, Alegre, ES, Brasil \\ ${ }^{5}$ Centro Regional de Desenvolvimento Rural, Centro Serrano, \\ Instituto Capixaba de Pesquisa, Assistência Técnica e Extensão Rural, \\ Domingos Martins, ES, Brasil \\ ${ }^{6}$ Programa de Iniciação Científica, Centro de Ciências Agrárias, \\ Universidade Federal do Espírito Santo, Alegre, ES, Brasil \\ Corresponding author: W.N. Rodrigues \\ E-mail: rodrigues@phytotechnics.com \\ Genet. Mol. Res. 15 (1): gmr.15017724 \\ Received September 24, 2015 \\ Accepted November 9, 2015 \\ Published February 5, 2016 \\ DOI http://dx.doi.org/10.4238/gmr.15017724
}

ABSTRACT. The present study was developed to respond to the need for an increase in crop yield in the mountain region of Caparaó (southern Espírito Santo State, Brazil), an area of traditional coffee production. This study aimed to analyze the diversity and characterize the crop yield of genotypes of Coffea arabica L. with potential for cultivation in high plant density systems. In addition, it also aimed to quantify the expression of agronomic traits in this cultivation system and provide information on the 
genotypes with the highest cultivation potential in the studied region. The experiment followed a randomized block design with 16 genotypes, four repetitions, and six plants per experimental plot. Plant spacing was $2.00 \mathrm{x}$ $0.60 \mathrm{~m}$, with a total of 8333 plants per hectare, representing a high-density cultivation system. Coffee plants were cultivated until the start of their reproductive phenological cycles and were evaluated along four complete reproductive cycles. Genotypes with high crop yield and beverage quality, short canopy, and rust resistance were selected. C. arabica genotypes showed variability in almost all characteristics. It was possible to identify different responses among genotypes grown in a high plant density cultivation system. Although the chlorophyll a content was similar among genotypes, the genotypes Acauã, Araponga MG1, Sacramento MG1, Tupi, and Catuaí IAC 44 showed a higher chlorophyll $b$ content than the other genotypes. Among these, Sacramento MG1 also showed high leafiness and growth of vegetative structures, whereas Araponga MG1, Pau-Brasil MG1, and Tupi showed high fruit production. In addition, Araponga MG1 had also a higher and more stable crop yield over the years.

Key words: Plant density; Coffea arabica; Crop yield; Biomass allocation; Chlorophyll

\section{INTRODUCTION}

Coffee cultivation in Brazil is an agricultural activity that plays an important role in the social and economic development of the country. It is especially important in the agribusiness, generating employment and keeping workers in the rural zones, but also as source of foreign exchange earnings (CONAB, 2015). In addition to its socio-economic importance, the tradition and historical trajectory of coffee cultivation is deeply connected to the historical trajectory of the country (Ferrão et al., 2008).

Although, with the use of new cultivation technologies, crop yield has been increasing, there is still the need to improve the productivity of Brazilian coffee plantations. This applies mainly for the mountain coffee cultivated in the State of Espírito Santo, where new cultivation technologies are available but have not yet been widely used. Among these technologies, using high plant densities has major advantages in terms of used area and soil protection, which is important for production systems based on family farming and for cultivation at mountains (Matiello et al., 2005). In addition, the availability of improved cultivars, which adds several advantages and facilities for cultivation, is another technology that should be used (Braccini et al., 2005).

To combine the use of high plant density with new improved cultivars, the behavior of different cultivars in this cropping system should be studied. This will allow the selection of a group of cultivars that require less space to grow and produce fruits. The variability in the response of Arabica coffee cultivars to the increase in plant density has been previously reported (Rodrigues et al., 2014a), indicating that it is possible to select cultivars that are more suitable for this cultivation system.

The present study was developed to respond to the need for an increase in crop yield in the mountain region of Caparaó (southern Espírito Santo State, Brazil). It aims to study the diversity and characterize the crop yield of genotypes of Coffea arabica L. that have a potential for cultivation in a system of high plant density. In addition, this study also aims to quantify the expression of agronomic traits in this cultivation system and provide information on genotypes with the highest cultivation potential in the studied region. 


\section{MATERIAL AND METHODS}

\section{Experimental setup}

The experiment was conducted in a competition field located in the district of Celina, municipality of Alegre, in the Caparaó region (southern Espírito Santo State, Brazil; $20^{\circ} 45^{\prime} S$ and $41^{\circ} 33^{\prime} \mathrm{W}$ ), where Arabica coffee is traditionally cultivated. The area has an altitude of $690 \mathrm{~m}$, an average annual temperature of $22^{\circ} \mathrm{C}$, and rainfall between 1300 and $1800 \mathrm{~mm}$ per year, with the rainy season from October to April and the dry season from May to September. The soil is classified as oxisol (local identification: Latossolo Vermelho-Amarelo).

Sixteen genotypes of Arabica coffee were cultivated following a randomized block design, with four repetitions and six plants per experimental plot. Plant spacing was $2.00 \times 0.60 \mathrm{~m}$, with a total of 8333 plants per hectare, representing a high-density cultivation system (Androcioli Filho and Androcioli, 2011). Agricultural practices were done in accordance with those normally employed in the area, according to the production need and following the current recommendations for the cultivation of Arabica coffee in Brazil (Prezotti et al., 2007; Reis and Cunha, 2010).

\section{Coffee genotypes}

Genotypes (16) of C. arabica (Table 1) originated from breeding programs of institutions that are world references in the development of cultivars of Arabica coffee, such as Instituto Agronômico de Campinas, Empresa de Pesquisa Agropecuária de Minas Gerais, Fundação ProCafé, and Instituto Agronômico do Paraná (IAPAR).

Genotypes with high crop yield and quality were selected, prioritizing genotypes with a short canopy and rust resistance. These agronomic characteristics are highly important in cultivation systems using high plant density (Carvalho et al., 2008).

Table 1. Characteristics of the genotypes used in this study.

\begin{tabular}{l|l|l|l|l}
\hline \multicolumn{1}{c|}{ Genotype } & Origin & Canopy size & Crop yield & Beverage quality \\
\hline Acauã & IBC/Procafé Breeding Program & Short & High & Good \\
\hline Araponga MG1 & EPAMIG/UFV Breeding Program & Short & High & Good \\
\hline Catiguá MG2 & EPAMIG/UFV Breeding Program & Short & High & Excellent \\
\hline Catiguá MG3 & EPAMIG/UFV Breeding Program & Short & High & Good \\
\hline Catucaí Amarelo 24/137 & IBC/Procafé Breeding Program & Short & High & Good \\
\hline Catuaí Vermelho IAC 44 & IAC Breeding Program & Short & High & Good \\
\hline Catuaí Vermelho IAC 81 & IAC Breeding Program & Short & High & Good \\
\hline Catuaí Vermelho IAC 144 & IAC Breeding Program & Short & High & Good \\
\hline H419-3-3-7-16-4-1-1 & EPAMIG/UFV Breeding Program & Short & High & Good \\
\hline IAPAR 59 & IAPAR Breeding Program & Short & High & High (first years) \\
\hline Katipó & IBC Breeding Program & Short & Good \\
\hline Oeiras MG 6851 & EPAMIG/UFV Breeding Program & Short & High & Good \\
\hline Paraíso MG H 419-1 & EPAMIG/UFV Breeding Program & Short & High & Good \\
\hline Pau-Brasil MG1 & EPAMIG/UFV Breeding Program & Short & High & Good \\
\hline Sacramento MG1 & EPAMIG/UFV Breeding Program & Short & High \\
\hline Tupi & IAC Breeding Program & Short & \\
\hline
\end{tabular}

Source: Carvalho et al. (2008). Instituto Brasileiro do Café (IBC); Fundação Procafé (Procafé); Empresa de Pesquisa Agropecuáriade Minas Gerais(EPAMIG); UniversidadeFederal de Viçosa(UFV); InstitutoAgronômicodeCampinas(IAC). 


\section{Crop yield, biomass allocation, and leaf ratios}

Plants were cultivated until the start of their reproductive phenological cycles and were evaluated along four complete reproductive cycles (harvests 2011-2014). At the end of each reproductive cycle, the number of reproductive nodes was determined by counting all gems along the plagiotropic branch that were visually differentiated in floral buds or growing fruits. Additionally, the number of fruits grown in each bud was counted and the length of the internodes was determined by measuring length in one basal, one median, and one apical internode of the plagiotropic branch.

Chlorophyll content in fully expanded leaves from the third and fourth pairs (from the apex) was determined using a portable chlorophyllometer (ClorofiLOG, CFL1030, Falker). Leaf chlorophyll $a$ and chlorophyll $b$ contents were measured and their ratio (chlorophyll $a / b$ ) was determined.

Plagiotropic branches were collected and transported to laboratory. In the laboratory, branches were cut to separate the stem, leaves, and fruits. Leaves were counted and analyzed with an area meter integrator (Area Meter, LI-3100C, Li-Cor, precision: $0.01 \mathrm{~cm}^{2}$ ) to determine the total leaf area per plagiotropic branch. The specific leaf area was determined from leaf discs of known area as the ratio between leaf area and leaf dry matter.

To determine the dry matter accumulation in stems, leaves, and fruits, each compartment was placed in paper bags and dried in an oven with forced air circulation at a temperature of $65^{\circ} \mathrm{C}$ until constant weight.

The leaf area ratio (LAR) was calculated as the ratio between leaf area and total dry matter of each plagiotropic branch. In addition, the stem mass ratio, leaf mass ratio and fruit mass ratio were calculated as the ratio between, respectively, stem, leaf, and fruit dry matter and total dry matter of the plagiotropic branch.

Each year, all ripe fruits were collected to calculate the annual crop yield of the cultivars. Fruits of each plot were harvested and weighed to determine total production (green coffee). Afterwards, fruits were dried, processed, and reweighed to determine the weight of the grains after processing (processed coffee). The processing ratio between processed and green coffee $\left(R_{\text {proc/green }}, \%\right)$ was then calculated as the processed coffee weight resulting from $2 \mathrm{~kg}$ green coffee.

The available leaf area per fruit $\left(\mathrm{cm}^{2}\right.$ per unit of fruit) in each plagiotropic branch was calculated as the ratio between leaf area and the number of fruits produced. The cumulative crop yield was determined as the processed coffee weight in each experimental plot considering the total number of plants per hectare, cultivated under the same plant density. Results are reported as the number of processed coffee bags (60 kg each) per hectare (bags/ha). The cumulative crop yield of the four years was estimated by determining plant production during the four cultivation periods, i.e., from planting until pruning.

Bienniality, which expresses the magnitude of the crop yield oscillation (bags/ha), was measured using the method proposed by Stevens (1949). Furthermore, samples of $1000 \mathrm{~g}$ processed coffee were classified in commercial sieves and the proportion of grains (\%) retained in sieves larger than sieve 16 were determined.

\section{Data analysis}

Results were expressed as the mean value or the accumulated value in four crops. Data were analyzed using analysis of variance (ANOVA), using the model $Y_{i j}=\mu+g_{i}+b_{j}+\varepsilon_{i j}$ and considering the effect of genotypes as fixed. In this model, $Y_{i j}$ represents the phenotypic value of the character for the $\mathrm{ij}^{\text {th }}$ observation, $\mu$ is the general mean, $g_{i}$ represents the effect of the $i^{\text {th }}$ genotype, 
$\mathrm{b}_{\mathrm{j}}$ represents the effect of the $\mathrm{j}^{\text {th }}$ block, and $\varepsilon_{\mathrm{ij}}$ is the random error. Means were analyzed using the Scott-Knott criteria (at 5\% probability). The genetic parameters for each variable were estimated using the methods described by Cruz and Carneiro (2003), whereby the values for quadratic phenotypic variability (), quadratic genotypic variability (), coefficient of genotypic determination $\left(\mathrm{H}^{2}\right)$, coefficient of genetic variation $\left(\mathrm{CV}_{\mathrm{g}}\right)$, and variation index $\left(\mathrm{CV}_{\mathrm{g}} / \mathrm{CV}\right)$ were estimated. Analyses were performed using the statistical software GENES (Cruz, 2013).

\section{RESULTS}

\section{Variability in crop yield, biomass allocation, and leaf ratios among genotypes}

Considering the mean values of the four harvests (2011-2014), a significant effect of genotype was found for most of the evaluated characteristics. Only chlorophyll a content and the ratio chlorophyll $a / b$ was the same among the genotypes evaluated in this study.

The $\mathrm{H}^{2}$ was high for characteristics related to fruit production (above $80 \%$ for 14 out of 18 variables). Similarly, the size and mass of produced fruits showed very high $\mathrm{H}^{2}$, not only for the characteristics related to leaf area but also for parameters of biomass allocation among the structures of plagiotropic branches.

In addition, $\mathrm{CV}_{\mathrm{g}} / \mathrm{CV}$ ranged from 0.53 to 4.75 for the different variables and was higher than 0.80 in $78 \%$ of the variables. This shows that genetic variation is higher than environmental variation, indicating favorable conditions for genotype selection.

\section{Leafiness and LARs in reproductive branches}

Genotype variation in terms of internode length was low (only two groups were identified using the Scott-Knott criteria). The genotypes Araponga MG1 and Catiguá MG3 presented compact internodes. Despite their small size, a large number of buds were formed in the plagiotropic branches (Table 2).

Three homogeneous genotype groups were identified based on the number of leaves per plagiotropic branch. The genotype Sacramento MG1 had the highest number of leaves (26) per reproductive branch, whereas the genotypes H419-3-3-7-16-4-1-1, Catiguá MG2, Catiguá MG3, and Catuaí IAC 44 formed a second group with 18-21 leaves per branch. The remaining genotypes formed a third group with smaller leaf numbers (Table 2).

Total leaf area exceeded $966 \mathrm{~cm}^{2}$ per branch in the genotypes Catiguá MG2 and Sacramento MG1, which formed the group with highest mean leaf area per branch. Despite having a smaller number of leaves, Catiguá MG2 presented a leaf area similar to Sacramento MG1. This indicates that the leaves of Catiguá MG2 were larger, resulting in a similar total area (Table 2). Catuaí Amarelo 24/137, Pau-Brasil MG1, and Oeiras MG 6851 had a smaller leaf area per branch when compared to the other genotypes.

High specific leaf area was observed in the genotypes Katipó, Paraíso MG H419-1, Araponga MG1, Catuaí Amarelo 24/137, Pau-Brasil MG1, Oeiras MG 6851, and Catuaí IAC 81, which produced larger and thinner leaves than other genotypes, resulting in a lower biomass (Table 2).

Considering the available leaf area per unit of fruit in the plagiotropic branch, there was a large variability among genotypes, with the formation of five homogeneous groups. The largest available leaf area was observed in the genotypes IAPAR 59 and Sacramento MG1, which presented over $9.27 \mathrm{~cm}^{2}$ of available area per fruit. These leaves, together with the leaves from the lower canopy (branches without fruit production in that particular cycle), are an important source of assimilates for supporting the metabolic demands of fruit production (Table 2). 
W.N. Rodrigues et al.

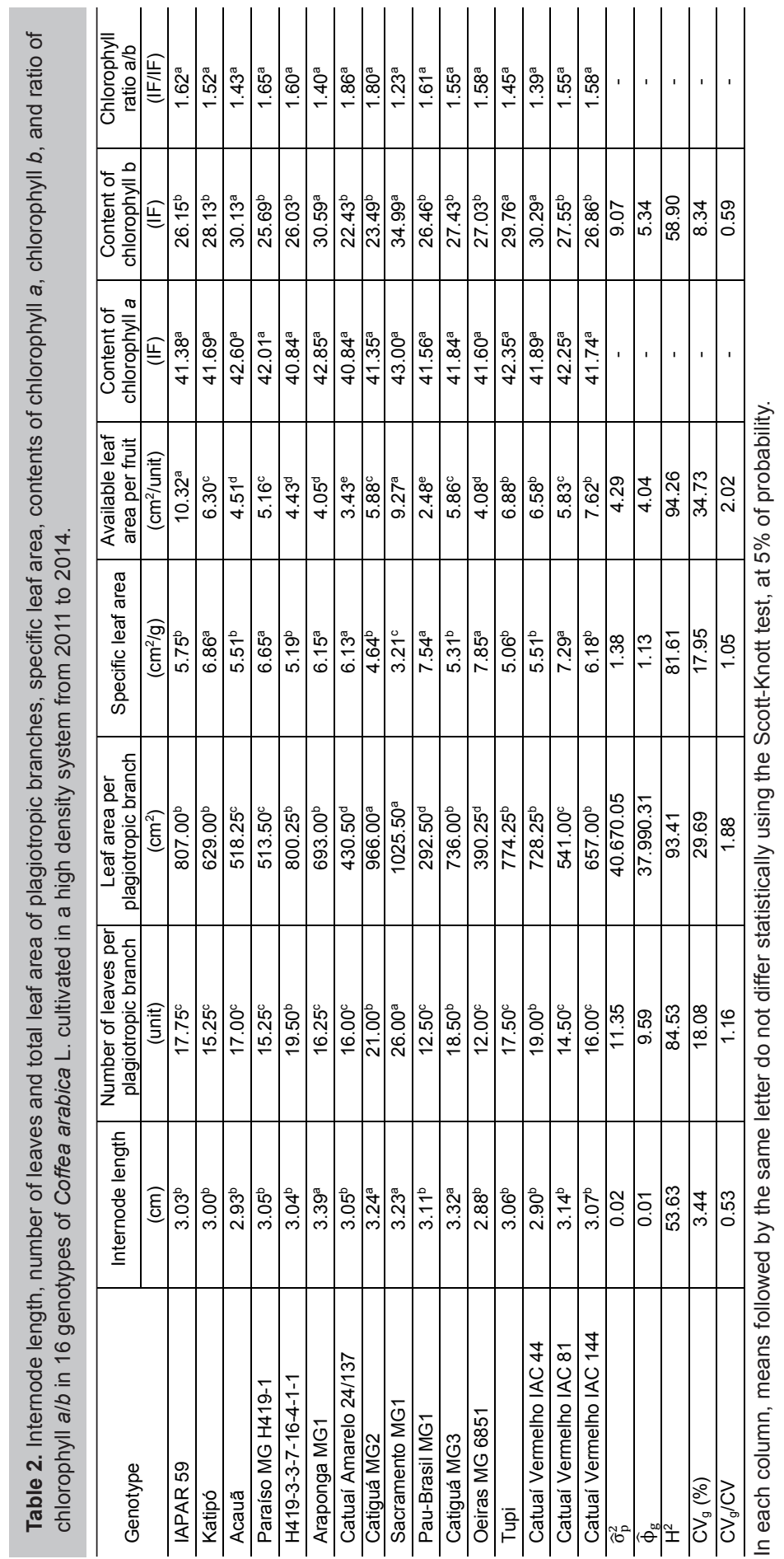


The content of chlorophyll a, which is involved in the electron transfer from water to the photosynthesis transport chain, did not vary among genotypes and had a mean value of 41.86 . In relation to chlorophyll $b$, which increases the range of the light spectrum absorbed by chloroplasts and transfers energy to the chlorophyll a molecule, differences were found among genotypes. The genotypes Acauã, Araponga MG1, Sacramento MG1, Tupi, and Catuaí IAC 44 showed the highest chlorophyll $b$ contents. However, since in the leaves of coffee plants chlorophyll a content is higher than that of chlorophyll $b$, differences found in chlorophyll $b$ content were not large enough to cause a difference in the ratio chlorophyll a/b (Table 2).

\section{Parameters of biomass allocation}

Differences in the leaf area ratio of plagiotropic branches have been found among genotypes, which were divided into four homogeneous groups. The highest leaf area ratios were found in the genotypes IAPAR 59, Sacramento MG1, and Catuaí IAC 144, with values higher than $15.23 \mathrm{~cm} / \mathrm{g}$. The lowest ratios were observed in genotypes Catuaí Amarelo 24/137, Pau-Brasil MG1, and Oeiras MG 6851, with values lower than $7.76 \mathrm{~cm} / \mathrm{g}$ (Table 3).

Table 3. Leaf area ratio, stem mass ratio, leaf mass ratio, and harvest index of plagiotropic branches in 16 genotypes of Coffea arabica L. cultivated in a high-density system from 2011 to 2014.

\begin{tabular}{|c|c|c|c|c|}
\hline \multirow{2}{*}{ Genotype } & Leaf area ratio & Stem mass ratio & Leaf mass ratio & Harvest index \\
\hline & $\left(\mathrm{cm}^{2} / \mathrm{g}\right)$ & $(g / g)$ & $(g / g)$ & $(g / g)$ \\
\hline IAPAR 59 & $15.97^{a}$ & $0.15^{\mathrm{b}}$ & $0.16^{b}$ & $0.69^{b}$ \\
\hline Katipó & $11.36^{b}$ & $0.11^{\mathrm{c}}$ & $0.11^{d}$ & $0.78^{a}$ \\
\hline Acauã & $8.79^{c}$ & $0.09^{d}$ & $0.10^{d}$ & $0.81^{a}$ \\
\hline Paraíso MG H419-1 & $12.91^{\mathrm{b}}$ & $0.14^{b}$ & $0.13^{c}$ & $0.73^{b}$ \\
\hline H419-3-3-7-16-4-1-1 & $10.69^{c}$ & $0.13^{b}$ & $0.11^{d}$ & $0.76^{b}$ \\
\hline Araponga MG1 & $9.47^{\mathrm{c}}$ & $0.11^{\mathrm{c}}$ & $0.10^{d}$ & $0.79^{a}$ \\
\hline Catuaí Amarelo 24/137 & $7.76^{d}$ & $0.11^{\mathrm{c}}$ & $0.08^{e}$ & $0.81^{a}$ \\
\hline Catiguá MG2 & $12.78^{b}$ & $0.13^{b}$ & $0.13^{c}$ & $0.74^{b}$ \\
\hline Sacramento MG1 & $17.96^{\mathrm{a}}$ & $0.20^{\mathrm{a}}$ & $0.22^{\mathrm{a}}$ & $0.58^{c}$ \\
\hline Pau-Brasil MG1 & $6.00^{d}$ & $0.13^{b}$ & $0.07^{e}$ & $0.80^{a}$ \\
\hline Catiguá MG3 & $12.13^{b}$ & $0.13^{b}$ & $0.13^{c}$ & $0.74^{\mathrm{b}}$ \\
\hline Oeiras MG 6851 & $6.95^{d}$ & $0.09^{d}$ & $0.08^{e}$ & $0.84^{a}$ \\
\hline Tupi & $11.63^{b}$ & $0.14^{\mathrm{b}}$ & $0.13^{c}$ & $0.73^{b}$ \\
\hline Catuaí Vermelho IAC 44 & $13.17^{b}$ & $0.11^{\mathrm{c}}$ & $0.13^{c}$ & $0.76^{b}$ \\
\hline Catuaí Vermelho IAC 81 & $13.00^{\mathrm{b}}$ & $0.13^{b}$ & $0.13^{c}$ & $0.74^{b}$ \\
\hline Catuaí Vermelho IAC 144 & $15.23^{a}$ & $0.13^{b}$ & $0.16^{b}$ & $0.71^{b}$ \\
\hline$\widehat{\sigma}_{\mathrm{p}}^{2}$ & 10.77 & 0.01 & 0.01 & 0.01 \\
\hline$\widehat{\phi}_{\mathrm{g}}$ & 9.89 & 0.01 & 0.01 & 0.01 \\
\hline $\mathrm{H}^{2}$ & 91.85 & 90.97 & 93.14 & 94.77 \\
\hline $\mathrm{CV}_{\mathrm{g}}(\%)$ & 27.09 & 18.53 & 30.06 & 7.85 \\
\hline $\mathrm{CV}_{\mathrm{g}} / \mathrm{CV}$ & 1.67 & 1.58 & 1.84 & 2.12 \\
\hline
\end{tabular}

In each column, means followed by the same letter do not differ statistically using the Scott-Knott test, at $5 \%$ of probability.

Stem biomass of the plagiotropic branches was highest in the Sacramento MG1 genotype, which accumulated up to $20 \%$ of the dry matter in the stem structure. In contrary, the genotypes Acauã and Oeiras MG 6851 had the lowest stem biomass, with a stem mass ratio lower than $9 \%$ (Table 3). Leaf mass ratio, showed a similar pattern, with the genotypes IAPAR 59, Sacramento MG1, and Catuaí IAC 144 having a higher ratio than the rest. Among these, the genotype Sacramento 
MG1 showed the highest mean, with approximately $22 \%$ of the plagiotropic branch biomass allocated to the leaves. The genotypes Catuaí Amarelo 24/137, Pau-Brasil MG1, and Oeiras MG 6851 showed the lowest means, with less than $8 \%$ of the biomass allocated to the leaves (Table 3 ).

The harvest index of the plagiotropic branches in Acauã, Araponga MG1, Catuaí Amarelo 24/137, Pau-Brasil MG1, and Oeiras MG 6851 was higher than in the other genotypes, in which more than $78 \%$ of the biomass was partitioned into fruits. The genotype Sacramento, which showed a large biomass allocation to stems and leaves, showed a smaller proportion of biomass directed to the fruits, with and harvest index of only $58 \%$ (Table 3 ).

\section{Reproductive nodes, crop yield, bienniality, and classification of the produced coffee}

For most cultivars, crop yield increased over the first three seasons. Fruit production was high in 2012 and 2013, resulting in a very high yield of the 2013 harvest. The following year, plants showed a reduction in productivity, which indicates a stronger effect of bienniality due to the high production and relatively low vegetative growth during the 2012-2013 cycle.

In terms of cumulative yield until pruning (after the fourth harvest), genotypes were divided into three homogeneous groups (Table 4). Araponga MG1, Pau-Brasil MG1, and Tupi showed a cumulative yield higher than 211 bags/ha during the four seasons (211.61, 227.60 and 246.61 bags/ha in the seasons 2011/2012, 2012/2013, and 2013/2014, respectively), and were the group with the highest crop yield.

Table 4. Cumulative crop yield, bienniality, processing ratio, proportion of grains retained in the sieves larger than sieve 16, number of reproductive nodes, and number of fruits per bud in 16 genotypes of Coffea arabica $\mathrm{L}$. cultivated in a high-density system from 2011 to 2014.

\begin{tabular}{|c|c|c|c|c|c|c|}
\hline \multirow[t]{2}{*}{ Genotype } & $\begin{array}{l}\text { Cumulative crop } \\
\text { yield in } 4 \text { years }\end{array}$ & Bienniality & $\begin{array}{c}\text { Processing ratio } \\
\text { (Rproc/green })\end{array}$ & $\begin{array}{c}\text { Sieve classification } \\
\text { over } 16\end{array}$ & $\begin{array}{l}\text { Number of } \\
\text { reproductive } \\
\text { nodes }\end{array}$ & $\begin{array}{l}\text { Number of } \\
\text { fruits per } \\
\text { bud }\end{array}$ \\
\hline & (bags/ha) & (bags/ha) & $(\%)$ & $(\%)$ & (unit) & (unit) \\
\hline IAPAR 59 & $106.55^{c}$ & $6.15^{d}$ & $24.09^{c}$ & $60.79^{c}$ & $10.50^{\mathrm{b}}$ & $7.54^{d}$ \\
\hline Katipó & $173.66^{b}$ & $16.40^{\mathrm{c}}$ & $22.64^{\mathrm{d}}$ & $79.88^{\mathrm{a}}$ & $11.00^{\mathrm{b}}$ & $9.49^{c}$ \\
\hline Acauã & $173.25^{b}$ & $14.90^{\mathrm{c}}$ & $24.20^{\mathrm{C}}$ & $62.26^{c}$ & $8.75^{\mathrm{d}}$ & $13.33^{b}$ \\
\hline Paraíso MG H419-1 & $148.43^{b}$ & $16.20^{\mathrm{c}}$ & $23.92^{\mathrm{c}}$ & $40.00^{\mathrm{e}}$ & $8.75^{d}$ & $11.31^{\mathrm{c}}$ \\
\hline H419-3-3-7-16-4-1-1 & $156.56^{\mathrm{b}}$ & $19.12^{\mathrm{c}}$ & $24.29^{\mathrm{c}}$ & $62.40^{\mathrm{c}}$ & $13.25^{\mathrm{a}}$ & $13.71^{\mathrm{b}}$ \\
\hline Araponga MG1 & $211.61^{a}$ & $13.62^{c}$ & $28.27^{a}$ & $61.37^{c}$ & $10.00^{c}$ & $17.28^{a}$ \\
\hline Catuaí Amarelo 24/137 & $183.12^{\mathrm{b}}$ & $29.27^{a}$ & $22.71^{\mathrm{d}}$ & $71.92^{\mathrm{b}}$ & $10.25^{\mathrm{b}}$ & $12.31^{\mathrm{b}}$ \\
\hline Catiguá MG2 & $191.09^{b}$ & $23.14^{\mathrm{b}}$ & $24.62^{b}$ & $39.22^{\mathrm{e}}$ & $13.00^{\mathrm{a}}$ & $12.75^{\mathrm{b}}$ \\
\hline Sacramento MG1 & $174.49^{b}$ & $15.76^{c}$ & $21.63^{\mathrm{e}}$ & $32.59^{f}$ & $11.50^{\mathrm{b}}$ & $9.68^{\mathrm{c}}$ \\
\hline Pau-Brasil MG1 & $227.60^{a}$ & $31.98^{\mathrm{a}}$ & $24.91^{\mathrm{b}}$ & $41.06^{\mathrm{e}}$ & $11.25^{\mathrm{b}}$ & $10.55^{\mathrm{c}}$ \\
\hline Catiguá MG3 & $158.86^{b}$ & $12.06^{c}$ & $23.08^{d}$ & $62.69^{c}$ & $10.75^{\mathrm{b}}$ & $11.79^{c}$ \\
\hline Oeiras MG 6851 & $167.50^{\mathrm{b}}$ & $7.54^{\mathrm{d}}$ & $22.36^{d}$ & $54.62^{\mathrm{d}}$ & $9.50^{\mathrm{c}}$ & $10.40^{\mathrm{c}}$ \\
\hline Tupi & $246.61^{a}$ & $25.60^{\mathrm{b}}$ & $22.74^{\mathrm{d}}$ & $69.42^{\mathrm{b}}$ & $11.00^{\mathrm{b}}$ & $10.21^{\mathrm{c}}$ \\
\hline Catuaí Vermelho IAC 44 & $173.73^{b}$ & $12.26^{\mathrm{c}}$ & $24.61^{b}$ & $66.43^{\mathrm{c}}$ & $10.50^{\mathrm{b}}$ & $10.62^{\mathrm{c}}$ \\
\hline Catuaí Vermelho IAC 81 & $159.73^{b}$ & $21.92^{\mathrm{b}}$ & $28.29^{\mathrm{a}}$ & $62.93^{c}$ & $8.25^{\mathrm{d}}$ & $11.31^{\mathrm{c}}$ \\
\hline Catuaí Vermelho IAC 144 & $129.07^{c}$ & $14.05^{\mathrm{c}}$ & $22.43^{\mathrm{d}}$ & $66.73^{\mathrm{c}}$ & $8.00^{d}$ & $10.95^{\mathrm{c}}$ \\
\hline$\widehat{\sigma}_{\mathrm{p}}^{2}$ & $1,195.77$ & 52.85 & 3.66 & 178.11 & 2.29 & 4.79 \\
\hline$\widehat{\phi_{g}}$ & $1,048.30$ & 48.28 & 3.62 & 174.85 & 2.05 & 4.48 \\
\hline $\mathrm{H}^{2}$ & 87.66 & 91.36 & 98.90 & 98.17 & 89.38 & 93.66 \\
\hline $\mathrm{CV}_{\mathrm{g}}(\%)$ & 18.62 & 39.71 & 7.92 & 22.64 & 13.79 & 18.49 \\
\hline $\mathrm{CV}_{\mathrm{g}} / \mathrm{CV}$ & 1.33 & 1.62 & 4.75 & 3.66 & 1.45 & 1.92 \\
\hline
\end{tabular}

In each column, means followed by the same letter do not differ statistically using the Scott-Knott test, at $5 \%$ of probability. 
Regarding the temporal variation in crop yield, the genotypes Catuaí Amarelo 24/137 and Pau-Brasil MG1 showed the highest variation, varying between 29.27 and 31.98 bags/ha between harvests. IAPAR 59 and Oeiras MG 6851 were the most stable genotypes, varying only 6.15 and $7.54 \mathrm{bags} / \mathrm{ha}$ (Table 4 ).

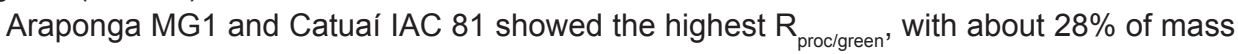
conversion from green to processed coffee. A higher number of fruits was required to produce the same amount of processed coffee in the genotypes Sacramento MG1, Katipó, Catuaí Amarelo 24/137, Catiguá MG3, Oeiras MG 6851, Tupi, and Catuaí IAC 144 (ratios varied between 22 and 23\%) (Table 4).

Grain size, which was classified with sieves, showed that the genotype Sacramento MG1 had the smallest grains, with only $33 \%$ of the grains being retained in sieves larger than sieve 16 .

Regarding the number of reproductive nodes per plagiotropic branch, the genotypes H419-3-3-7-16-4-1-1 and Catiguá MG2 presented the largest number of buds, with more than 13 reproductive nodes per branch. The genotypes Acauã, Paraíso MG H419-1, Catuaí IAC 81, and Catuaí IAC 144 showed the lowest number of reproductive nodes, with mean values lower than 8.75 nodes per branch (Table 4).

The genotype Araponga MG1 was able to maintain a large number of fruits per node during maturation (17.28 fruits). The group of genotypes formed by Acauã, H419-3-3-7-16-4-1-1, Catuaí Amarelo 24/137, and Catiguá MG2, produced 12.31-13.71 fruits per node, while the lowest fruit production per node was observed in the genotype IAPAR 59 (7.54 fruits) (Table 4).

\section{DISCUSSION}

The biometry regarding most of the agronomic traits evaluated in this experiment were highly valuable to study the diversity of the genotypes. Characteristics such as the number of reproductive nodes, number of leaves, leaf area, specific leaf area, chlorophyll content and area, and mass ratios have been previously used in biometric studies of diversity among genotypes of Arabica coffee and showed high genetic variability in some of these traits (Rodrigues et al., 2014a). Oliveira et al. (2011) also observed a considerable genetic variability among genotypes of Arabica coffee, which was enough to allow selection gains based on crop yield, both using the first high harvest only and the mean of the first four harvests.

High values of $\mathrm{H}^{2}$ were observed, corroborating the results of Teixeira et al. (2013), who found similar estimates for crop yield in genotypes of Arabica coffee grown in warm tropical regions. These authors showed that, despite being influenced by environmental factors, crop yield is also genetically determined.

Regarding the leafiness, Carvalho et al. (2012) also found variability in leaf and fruit ratios in genotypes of Arabica coffee, which was probably related to an intrinsic characteristic of some genotypes. Sacramento MG1 presented high leafiness (more and larger leaves), which explains the high ratio between leaf area and number of fruits. On the other hand, the small number of fruits and low leafiness of the genotype IAPAR 59 also contributed to a large available leaf area.

Catuaí Amarelo 24/137 and Pau-Brasil MG1 showed a small available leaf area, showing a discrepancy in terms of sources and sinks of photoassimilates. This may explain the greater effect of bienniality in these genotypes. As fruit formation is prioritized, acting as a metabolic drain, it is possible that assimilate production is insufficient to support the development of vegetative structures, limiting fruit production in the following year.

In addition to leafiness, the phytosanitary quality of the leaves is also an important 
parameter related to plant quality. High plant density cultivation systems often modulate the microclimatic conditions in the canopies, such as the overall temperature, humidity, and wetting time, which may promote or limit the development of different pathogens. In the region where this experiment was developed, the main coffee diseases are the leaf rust and the brown-eye spot, both caused by a fungus (Hemileia vastatrix and Cercospora coffeicola, respectively). Rodrigues et al. (2014b) have shown that, by following the occurrence of leaf spots in plagiotropic branches of $C$. arabica, it is possible to identify different levels of genotype resistance to certain diseases occurring in high density cultivation systems. Genotypes with high genetic resistance to the leaf rust fungus have been observed in these systems.

Regarding the production of fruits, in competition assays in the same region in which plant spacing was wider, the genotype Pau-Brasil MG1 also showed superiority in terms of crop yield, and the genotypes and progenies of the series Catiguá, Catucaí Amarelo, and Oeiras MG 6851 had high production capacity (Ferrão et al., 2013). This shows that these genotypes are well adapted to the conditions of the region of Caparaó, suggesting that these improved cultivars have a high potential for cultivation in this area. Moreover, results observed in this study for the genotype Tupi are consistent with those observed in other assays carried out in the State of Espírito Santo, which has led to the recommendation for cultivation of Tupi cultivars in this region (Ferrão et al., 2008; Ferrão et al., 2011).

Genotypes belonging to the two highest crop yield groups, such as Catiguá MG2 and Catucaí Amarelo 24/137, were shown to have high productivity in areas north of Rio de Janeiro (southeast coast of Brazil) (Rodrigues et al., 2014c). Similarly, Pau-Brasil MG1 and Catucaí Amarelo 24/137 were also considered suitable for cultivation in the State of Minas Gerais (southeast region Brazil), due to their constant yield and adaptability to different environments (Carvalho et al., 2012). Catucaí Amarelo 24/137, Acauã, Tupi, and Araponga MG1 also have been described as having a high cultivation potential in warmer tropical regions (Teixeira et al., 2013).

The genotypes IAPAR 59 and Catuaí IAC 144 showed low cumulative crop yield over the four years (respectively, 106.55 and 129.07 bags/ha). Ferrão et al. (2013) have also observed in the Caparaó region that genotypes from the Catuaí group and IAPAR 59 were inferior in terms of productivity. However, it should be pointed out that the low crop yield achieved by these genotypes in this high plant density system was still about $173 \%$ higher than the average yield of the region and about $63 \%$ higher than the average yield of the State of Espírito Santo, considering the same years (CONAB, 2015).

The effect of bienniality is attributed to stress caused by major metabolic demands during years of high fruit production, affecting the growth of branches and, therefore, limiting the production in the following year (DaMatta et al., 2007). Increasing plant density may reduce this oscillation between harvests by conditioning the plants to produce less fruits, reducing metabolic stress. Nevertheless, a high productivity still observed due to the large amount of plants produced per area. This approach can delay the depletion of reserves in the plants and decrease the effect of bienniality over the cycles (Pereira et al., 2007).

In addition, the genotypes Paraíso MG H419-1, Catiguá MG2, and Pau-Brasil MG1 also showed relatively small grains. The genotype Katipó had the highest proportion of grains retained in sieves larger than sieve 16 (80\%) (Table 4). Rodrigues et al. (2014c) described Catiguá MG2 as having a satisfactory classification of grain size when compared to other cultivars grown in the northern State of Rio de Janeiro. Moreover, these authors point out the importance of classifying cultivars according to grain size, similarly as done in the product market. It is also important to standardize grain mass for drying and roasting processes, since differences between processing techniques lead to differences in the organoleptic characteristics of the product, impairing its color and flavor. 
In conclusion, $C$. arabica genotypes showed variability in almost all characteristics related to crop yield, biomass allocation, and leaf ratios. It was possible to identify different responses among genotypes grown in a high plant density cultivation system. Although the chlorophyll a content was similar among genotypes, some genotypes, such as Acauã, Araponga MG1, Sacramento MG1, Tupi, and Catuaí IAC 44, showed higher chlorophyll $b$ content. Among these, Sacramento MG1 also showed high leafiness and growth of vegetative structures, whereas Araponga MG1, PauBrasil MG1, and Tupi showed high fruit production. In addition, Araponga MG1 had also a higher and more stable crop yield over the years.

\section{Conflicts of interest}

The authors declare no conflict of interest.

\section{ACKNOWLEDGMENTS}

The authors are grateful to Centro de Ciencias Agrárias of the Universidade Federal do Espírito Santo (CCAUFES) for providing access to the necessary facilities and laboratories. The authors would like to thank the Conselho Nacional de Desenvolvimento Científico e Tecnológico (CNPq), the Fundação de Amparo à Pesquisa do Espírito Santo (FAPES) and the Coordenação de Aperfeiçoamento de Pessoal de Nível Superior (CAPES) for awarding scholarships to the authors and for financially supporting this research.

\section{REFERENCES}

Androcioli Filho A and Androcioli LG (2011). Adensamento e poda do café arábica. In: Tecnologias para a sustentabilidade da cafeicultura (Tomaz MA, Amaral JFT, Jesus Junior WC, Fonseca AFA, Ferrão RG and Ferrão MAG, eds.). Caufes, Alegre, 69-94.

Braccini AL, Scapim CA, Vidigal Filho OS, Braccini MCL, et al. (2005). Características agronômicas e produção de frutos e grãos em resposta ao aumento na densidade populacional do cafeeiro. Acta Sci. Agron. 27: 269-279. http://dx.doi.org/10.4025/actasciagron.v27i2.1845

Carvalho AM, Mendes ANG, Botelho CE and Oliveira ACB (2012). Desempenho agronômico de cultivares de café resistentes à ferrugem no Estado de Minas Gerais, Brasil. Bragantia 71: 481-487. http://dx.doi.org/10.1590/S0006-87052013005000007

Carvalho CHS, Fazuoli LC, Carvalho GR, Guerreiro Filho O, et al. (2008). Cultivares de café arábica de porte baixo. In: Cultivares de café (Carvalho CHS, ed.). Embrapa Café, Brasília, 157-226.

CONAB (2015). Acompanhamento da safra brasileira: café, safra 2015, primeiro levantamento. Conab, Brasília.

Cruz CD (2013). GENES - a software package for analysis in experimental statistics and quantitative genetics. Acta Sci. Agron. 35: 271-276. http://dx.doi.org/10.4025/actasciagron.v35i3.21251

Cruz CD and Carneiro PC (2003). Modelos biométricos. UFV, Viçosa.

DaMatta FM, Ronchi CP, Maestri M and Barros RS (2007). Ecophysiology of coffee growth and production. Braz. J. Plant Physiol. 19: 485-510. http://dx.doi.org/10.1590/S1677-04202007000400014

Ferrão RG, Fornazier MJ, Ferrão MAG, Prezotti LC, et al. (2008). Estado da arte da cafeicultura no Espírito Santo. In: Seminário para a sustentabilidade da cafeicultura (Tomaz MA, Amaral JFT, Jesus Junior WC and Pezzopane JRM, eds.). Caufes, Alegre, 29-48.

Ferrão MAG, Fonseca AFA, Ferrão RG, Verdin Filho AC, et al. (2011). Cultivares de café arábica e conilon recomendados para o Estado do Espírito Santo. In: Tecnologias para a sustentabilidade da cafeicultura (Tomaz MA, Amaral JFT, Jesus Junior WC, Fonseca AFA, Ferrão RG and Ferrão MAG, eds.). Caufes, Alegre, 51-68.

Ferrão MAG, Fonseca AFA, Ferrão RG, Riva-Souza EM, et al. (2013). Desempenho de genótipos de café arábica avaliados na região do Caparaó Capixaba. In: Anais do $8^{\circ}$ Simpósio de Pesquisa dos Cafés do Brasil (Guerra AF, ed.). Embrapa, Salvador, 1-5. 
Matiello JB, Santinato R, Garcia AWR, Almeida SR, et al. (2005). Cultura de café no Brasil: novo manual de recomendações. Mapa/Procafe, Varginha.

Oliveira ACB, Pereira AA, Silva FL, Rezende JC, et al. (2011). Prediction of genetic gains from selection in Arabica coffee progenies. Crop Breed. Appl. Biotechnol. 11: 106-113. http://dx.doi.org/10.1590/S1984-70332011000200002

Pereira SP, Guimarães RJ, Bartholo GF and Guimarães PTG (2007). Crescimento vegetativo e produção de cafeeiros (Coffea arabica L.) recepados em duas épocas, conduzidos em espaçamentos crescentes. Cienc. Agrotec. 31: 643-649. http://dx.doi.org/10.1590/S1413-70542007000300007

Prezotti LC, Gomes JA, Dadalto GG and Oliveira JA (2007). Manual de recomendação de calagem e adubação para o Estado do Espírito Santo: $5^{\mathrm{a}}$ aproximação. Seea/Incaper/Cedagro, Vitória.

Reis PR and Cunha RL (2010). Arabica coffee: from sowing to harvest. Epamig, Lavras.

Rodrigues WN, Tomaz MA, Amaral JFT, Ferrão MAG, et al. (2014a). Biometrical studies on characteristics of plagiotropic branches in Coffea arabica L. cultivated with high plant density. Aust. J. Crop Sci. 8: 1239-1247.

Rodrigues WN, Tomaz MA, Apostólico MA, Colodetti TV, et al. (2014b). Severity of leaf rust and brown eyespot in genotypes of Coffea arabica L. cultivated with high plant density. Am. J. Plant Sci. 5: 3702-3709. http://dx.doi.org/10.4236/ajps.2014.525386

Rodrigues WP, Vieira HD, Barbosa DHSG, Sousa Filho GR, et al. (2014c). Agronomic performance of arabica coffee genotypes in northwest Rio de Janeiro State. Genet. Mol. Res. 13: 5664-5673.http://dx.doi.org/10.4238/2014.July.25.22 PubMed

Stevens WL (1949). Analises estatísticas do ensaio de variedades de café. Bragantia 9: 103-123.

Teixeira AL, Souza FF, Pereira AA, Oliveira ACB, et al. (2013). Performance of Arabica coffee cultivars under high temperature conditions. Afr. J. Agric. Res. 8: 4402-4407. 